\title{
The Cinema Authorship of Lindsay Anderson: Anderson's Directorial Practice
}

\author{
ISABELLE GOURDIN-SANGOUARD, UNIVERSITY OF STIRLING
}

\begin{abstract}
The following paper will investigate Lindsay Anderson's vision for the role of the film director; more specifically, his belief in the interdependency of the concepts underpinning the artist's integrity and the film critic's commitment to the artistic nature of the filmmaking process. The resulting dynamic captures the essence of Anderson's directorial practice by exposing his distinctive approach to filmmaking: one that sees the director as relying upon the input and expertise of his collaborators but that ultimately posits the director as the sole authority for the act of creation itself.
\end{abstract}

Three axes will structure the paper: first, a definition of the dynamic underpinning Anderson's work, with an emphasis upon the origin of the duality that informs his directorial practice: the figure of the film critic will contribute to laying bare the definition of the said dynamic. Second, an investigation into the resulting tension that manifests itself both at the level of production and within the finished film. And lastly, the paper will evaluate the impact of Anderson's directorial practice upon the 'Britishness' of his films.

\section{KEYWORDS}

Lindsay Anderson, sequence, film criticism, directorial practice, British Cinema

\section{INTRODUCTION}

Lindsay Anderson's career spanned nearly fifty years: starting in 1946 with his first documentary film - Meet The Pioneers ${ }^{1}$ - and ending in 1994 shortly after directing another documentary for BBC television about his career as a film director, ${ }^{2}$ Anderson was also associated with the British New Wave (Lay, 2002, p.57-60; Leach, 2004, p.53 \& 190; Pilard, 1996, p.73-7): in 1963 he directed This Sporting Life, the last contribution to a series of films - also referred to as 'Kitchen-Sink' realism by their detractors (Lay, 2002, p.67-8) - that aimed to present a more relevant picture of contemporary Britain. He also was a film critic launching his own film magazine Sequence, ${ }^{3}$ and regularly contributing reviews to Sight and Sound, The New Left Review, New Statesman, The Observer and The Times. Anderson proved a prolific and successful theatre director too, producing more than forty plays throughout his career, mostly for The Royal Court Theatre in London. He also directed six episodes of the Robin Hood series as well as a number of commercials for British television in the fifties and sixties. Nevertheless, he saw himself as a film director first and foremost. 
The following paper aims to introduce and investigate the nature of Anderson's directorial practice by looking at a selection of his writings about the practice of film criticism and filmmaking as well as two of his films, The White Bus (1967) and If... (1968). The first axis of the paper uncovers the existence of a constitutive tension that underlies Anderson's vision of the directorial process. The second axis focuses upon the circumstances surrounding the production and (lack of) distribution of The White Bus. This, Anderson's second feature film, illustrates the workings of the tension or duality that informs the director's work. The final section examines the impact that this constitutive tension had upon Anderson's work, both in terms of form and content, as well as from the point of view of his working pattern with his collaborators and the critical appraisal of his films. If .... and to a lesser extent The White Bus, help bring out the distinctiveness of his work as a British director.

\section{A CONSTITUTIVE TENSION: LINDSAY ANDERSON'S DEFINITION OF THE FILM-ARTIST AND THE FILM CRITIC'S ROLE IN THE FILMMAKING PROCESS}

In his early writings about film, Anderson placed an emphasis upon the concept of artistic integrity which he defined in terms of opposition to the detrimental role which he believed the British film critic too often played in the appreciation of film as an art form. ${ }^{4}$

In an article, 'Angles of Approach' (1947, p.189-93), which Anderson wrote for the second issue of the magazine Sequence in 1947, he set forth a vision for the cinematic artist whereby the true measure of artistic value lay in the artist's ability to achieve his/her goals within the completed film. ${ }^{5}$ Anderson privileged a vision for the role of the film director which promoted the idea of creative freedom and consequently called for the film critic's openmindedness. Anderson notably argued for the need on the part of the film critic to set aside prejudices or preconceived ideas as to the role film ought to play within society:

The first duty of the artist is not to interpret, nor to propagandise, but to create. And to appreciate that a genuinely creative work of art involves the willingness to jettison our own prejudices and viewpoints, and to accept those of the artist. (ibid., p.193)

His call upon the critic to apply a discerning eye to the appreciation of film, contributes to creating a complementary definition of the concept of artistic integrity. An artist should aim at materialising his/her artistic vision, notwithstanding the society's demands or expectations; similarly the critic ought to develop a set of aesthetic criteria that rest upon the highest standard of artistic accountability. In that sense 'Angles of Approach' provides an early template for Anderson's aesthetic principles: these would parallel his classification of films on the basis of a first-rate or second-rate system (ibid., p.190, 193). For Anderson these are mutually exclusive categories, and as a result, critical appreciation of the cinema also precludes the assimilation of one type of film with the other:

If you enjoy [sic] L'Eternel Retour, you may enjoy also King Kong, but not Black Narcissus. If you enjoy Black Narcissus, you cannot enjoy L'Eternel Retour. (If you think you enjoyed both, you are wrong.) There is ultimately, only one angle of approach; it will cover all that is good, but it cannot be broadened to include the second-rate. 'Prove all things: hold fast that which is good.' ... (ibid., p.193)

Independently of the validity of such a claim, Anderson's categorisation of films heralds a critical practice which amounts to a political manifesto: the critic and by extension the public at large, is expected to take a side. In other words, just as a given film reflects the degree of 
integrity displayed by the artist/filmmaker, the critic and the public are similarly urged to commit to the films they choose to see.

Roughly a decade later in 1956, Anderson contributed an article for Sight and Sound, 'Stand up! Stand Up!' (1956, p.218-32), which once more took as its central argument the dynamic underpinning the filmmaker-film critic relationship. Speaking of 'an implicit standard of judgement' in his own writings about film (Anderson, 1956, p. 218), Anderson offered a definition of artistic integrity which explicitly connected the respective notions of aesthetic and artistic commitment:

Style is important [...] and in the best art, anyway, style and commitment are inseparable. (ibid., p.219)

In order to clarify the nature of the link that underlies style and commitment in film, Anderson also relied upon the role that the film critic should play in the process of defining film as an art form. Echoing the argument he had developed in 'Angles of Approach' in 1947, Anderson underlined the film critic's tendency to thwart the cinema's aspirations to be treated as an art form. Quoting from established film reviewers for the British press such as C.A. Lejeune who in The Observer had declared that 'film [was] nothing but 'bits of celluloid and wire" or Kenneth Pearson, who had defined film as a 'craft, capable on rare occasions, of producing a work of some significance' (ibid., p.221), Anderson proceeded to offer his artistic vision for the cinema: 'It is a matter of fact, not of opinion, that the cinema is an art' (ibid., p.224).

For Anderson, granting the cinema the status of an art form was tantamount to acknowledging the true challenges which underpinned the filmmaking process both for the director/artist and for the film critic that appraised the finished film. This is where Anderson's key concept of the 'poetic' of film comes in:

... I find this distinction between form and content somewhat naif. It is the essence of poetry (in any medium) that the thing said cannot be critically distinguished from the way of saying it. (ibid., p.227)

In a way that paralleled his classification of film along the lines of first or second rate, Anderson turned his attention to the practice of writing about film by privileging the analysis of style to the detriment of content in order to allegorise the issue of artistic commitment in film: According to Anderson, the prevailing attitude in film criticism regarded ' analytical criticism [as] unwise, abnormal - even when it expose[d] covert propaganda ...' (ibid., p.228)

Anderson's pairing of the notion of artistic integrity along with the poetic at the heart of the artist-filmmaker's project, became visible when he invoked the set of values which he had seen as pivotal in assessing the filmmaker's artistic endeavour in 'Angles of Approach': in 'Stand Up! Stand Up!' the notions of artistic integrity and freedom of creation become the 'liberal' values which according to Anderson, while underpinning the British approach to the arts were nevertheless subject to constant social and cultural assaults. As a result, Anderson was quick to castigate the prevailing attitude that dismissed these values and instead reaffirmed the social and moral duty to stand up for them (Anderson, 1956, p. 231). Anderson's definition of liberalism in terms of a humanist approach to social and cultural life provides the background against which his aesthetic as a film director can be understood. Just as he insisted upon the co-existence but absence of commonality between first and secondrate films in the cinema, his aesthetic is also based upon a concept of duality: 
Our ideals - moral, social and poetic - must be defended with intelligence as well as emotion; and also with intransigence. (ibid., p.231)

This article will set out to explore Anderson's directorial signature by relying upon the framework suggested by the director's critical writings. Drawing upon the implied dichotomy that Anderson saw at the heart of the making of film on the one hand and its critical appraisal on the other, the following pages will build a framework within which it becomes possible to visualise and define the director's style and aesthetic. The White Bus (1967), and If... (1968) provide the visual and thematic expression of this duality.

\section{THE WHITE BUS AS ANALOGY OF THE DUALITY OR TENSION UNDERPINNING ANDERSON'S DIRECTORIAL PRACTICE}

Anderson referred to The White Bus as an 'unknown' film (Anderson, 2004b, p.107): it was never widely distributed nor exhibited. Positive auspices had however seen the birth of the project. In 1965 Oscar Lewenstein, an artistic director in the theatre turned film producer and personal friend of Anderson's, initiated a three-film project for Woodfall Films that aimed to reunite the three leading figures of the Free Cinema movement. In Anderson's words:

[Lewenstein] wanted to bring three directors of original personality together, to make a film in three segments. His first idea was that these pictures should not be related in any way, except that each should represent the free choice of its director.

Anderson (1979: LA 1/4/5/1)

Anderson opted to work on a short story by Shelagh Delaney (1964), entitled The White Bus. It was not the first time that Delaney had teamed up with Woodfall as back in 1961, her novel A Taste of Honey had been turned into a film directed by Tony Richardson. The White Bus was originally published in 1964 as part of a collection entitled Sweetly Sings the Donkey. The film's narrative follows a young woman over a period of two days, starting in London at the end of her day's work before she sets out on a journey to an unnamed city. Reviews typically referred to this city as being the Girl's hometown, Salford in the north of England, inferring that Delaney and Anderson had kept the same location as in the short story (Hedling, 1998, p.62; Sussex, 1970, p.58; Lambert, 2000, p.130). There, she boards a white touring bus displaying a big 'See Your City' sign on the side, which takes her on a guided tour of its key sites. She travels with the mayor and his mace-bearer - in full regalia - and a group of anonymous passengers wearing their national costumes or a stylised version of their best clothes. At the end of the day, involving a trip to a foundry, local school, the library, the museum, and the art gallery and ending with a civil defence demonstration, the Girl works her way back through the empty streets and stops at a fish-and-chips shop. The scene of her eating alone while the couple managing the shop are clearing the tables, concludes the film.

Publicly, Lindsay Anderson consistently professed a great fondness for The White Bus. ${ }^{6}$ The degree of creative latitude he was granted on the project played a significant part in his positive evaluation of the film:

I was very lucky in that Oscar [Lewenstein] gave me complete freedom. Looking back on things, I now realise that I have only been any good ... when making films entirely freely and in my own way ... Anderson (2004b: 105) 
When looking at Anderson's diaries for the period covering the scripting phase of The White Bus, a similar pattern emerges whereby Anderson demonstrated the confidence to actively contribute his own ideas to the project, even before filming was due to begin:

13 March 1965: Shelagh [Delaney] arrives ... We talk about the project ... She is sympathetic, direct, and I feel creative. Wish something could happen to make it more real for me. We agree to do it - I am encouraged by her liking the 'Songs of the Tyne', and even suggesting 'Blaydon Races' for the picture.

(Anderson, 2004a, 105)

Another entry into Anderson's diary for 1965 sheds a complementary light upon the dynamic that was to characterise his partnership with Delaney:

6 May 1965: SHELAGH at 11 - she has worked on the story - but hadn't brought her papers! Our chat remained vague, yet creative I think - suggestive rather, and I have confidence (hopeful) that something concrete and individual and poetic will emerge. I showed her THE DREAMLAND Express: which she understood: and we chatted about the style - the beginning - the end - the crucial mid-point where the bus arrives and a sort of realism (however personal) changes into a sort of fantasy (however concrete). I long just to 'do it'. No use at discussing scripts really.

(Anderson, 1965: LA 6/1/48)

Anderson appeared to attribute the initiative of the scripting stage to Delaney - 'she has worked on the story' - while at the same time, asserting a form of authorial control over the result - 'our chat remained vague ... I have confidence that something concrete and individual and poetic will emerge'. In other words, to Anderson it was her story, she was the one working on it, but their creative meetings shaped that same story into the filmable script.

The tension between what Anderson wanted to control and what he knew he could effectively control, illustrates a fundamental aspect of his directorial practice: a claim to authorial control that expresses itself through a contrary pull: Anderson acknowledged his collaborator's area of expertise and thereby predicated his own upon her successful and timely input in order for him to play his part. In other words, Anderson's authorial claim is the product of a paradox: the more effective the collaboration, the clearer his authorial input becomes and therefore the more effectively he can perform and claim the role of film director as his own alone.

The pattern was further visible in the circumstances that had led Anderson and Delaney to work together. As previously mentioned, Oscar Lewenstein had brought in Anderson, Karel Reisz and Tony Richardson to work on the project. Soon after giving the directors free rein as to the choice of subject, the project began to shape up around the idea of releasing a triptych of short films all using Shelagh Delaney material as their common thread. ${ }^{7}$ Anderson asserted his authorship over the project through an initial resistance to Lewenstein's suggestion, which later translated into a similar pattern of constructive reluctance when he started work with Delaney (Anderson, 2004a, 112; 116; 121; 124; 133; 134; 136). In other words, Anderson asserted his authorial control over the filmmaking process by shaping the collaborative work it entailed according to his vision for the film. This aspect of Anderson's directorial practice is key to understanding the view that he held of his role as a film director. The ultimate failure of the project illustrates this further. 
Karel Reisz withdrew at an early stage and Peter Brook stepped up in his place (Anderson, 1979, LA 1/4/5/1; Sussex, 1970, 55). ${ }^{8}$ According to the archival and published material accounting for that period of Anderson's career (Sussex, 1970, p.55; Lambert, 2000, p.134; Anderson, 2004b, p.107; Anderson, 1979, LA 1/4/5/1), Richardson and Brook would have started work on their respective segments also using Delaney as a primary source. Anderson completed his segment in 1966, ahead of his colleagues. A screening of The White Bus was arranged which Anderson claimed, prompted his fellow-directors to re-evaluate the nature of their contribution to the project. ${ }^{9}$ Anderson attributed the failure of the project - in creative terms - to his fellow directors' decision to abandon Delaney's material. In that respect, the programme notes which Anderson wrote in 1979 on the occasion of a screening of The White Bus at North Texas State University in Dallas, TX, United States (Anderson, 1979, LA $1 / 4 / 5 / 1$ ), provide an illustration of his belief that the absence of commonality in the directors' choice of subject caused the ultimate failure of the project:

...we (that is, Shelagh Delaney and I) heard that both Tony [Richardson] and Peter [Brook] had decided to jettison their Delaney subjects and go for something more striking and original. (I have never known whether to take this as a compliment, or the reverse). In the end, Tony made a forty-minute musical, in which Vanessa Redgrave sang six or seven songs; and Peter made a two-reel 'hommage' to Buster Keaton with Zero Mostel. Neither of these efforts was very successful in itself - and when the three films were put together, the result was a mysterious and uneven mish-mash. I suggested the title of RED, WHITE AND ZERO for the completed work, Tony's film being called 'Red and Blue', mine 'The White Bus', and Peter's starring Zero Mostel. United Artists took delivery, and the rest was (understandably) silence. (ibid.)

Anderson's ultimate condemnation of Richardson's and Brook's creative licence ${ }^{10}$ brings out the distinctiveness of his vision for the director's function: one that acknowledges his limitations within the filmmaking process and by implication expects the highest degree of commitment on the part of his collaborators. In the aforementioned programme notes, Anderson gave an insight into his working pattern as a director: he described the nature of his collaboration with the scriptwriter, which uncovers the point at which the tension characterising his directorial style, becomes apparent. In those notes, Anderson described the process whereby he switched from the collaborative to the individual. In other words, the collaborative work in which he would engage on his filmmaking projects, acted as a trigger for his directorial practice, the point at which he asserted his directorial authority. To quote him:

Shelagh and I worked closely together to produce a script which derived closely from the original story, but which went a good way beyond it... I think it was while we were working on the script that the idea came of injecting short bursts of colour into an otherwise black-and-white narrative ... Clearly what I was groping towards was a style that would be poetically expressive rather than naturalistically faithful to 'real life'. (ibid.)

It follows that Anderson conceived of his aesthetic as a film director as the result of a collaborative process, which the subtle shift from the 'we' to the 'I' personal pronoun indicates. While the recognition of the collaborative nature of the filmmaking process is not in itself unusual on the part of a film director, Anderson's acute awareness of the existence of a creative interaction that operates during his filmmaking projects is. This finds confirmation in his subsequent mention of Miroslav Ondricek's work on The White Bus: '... and so began a collaboration which was to be of the greatest importance for me, personally as well as creatively...' (ibid.) 


\section{THE SECOND ASPECT OF ANDERSON'S DIRECTORIAL STYLE: CONFRONTATION AS A CREATIVE TOOL}

Around the time of The White Bus's release, Anderson vented his frustration at the lack of commercial prospect for his film by attacking the narrow-mindedness of the film industry whose financial considerations in his opinion stifled the creative potential of more daring filmmakers (Sussex, 1970, p.57). In his attack Anderson compared the film distributors with the film critics that he judged just as incapable or unwilling to commit to the truly artistic as their bias in favour of the commercially tried and safe demonstrated. ${ }^{11}$ Anderson's reaction to the critical appraisal of The White Bus introduces the second facet of the concept of duality underpinning his directorial style: duality as a sustained confrontation between the needs of the individual and those of the society surrounding him/her.

The idea of confrontation is a logical extension to the argument presenting Anderson's directorial practice as the result of a tension between his individuality and the demands of his collaborators. However, where the concept of constitutive tension uncovers the nature of Anderson's directorial practice, the notion of confrontation delineates the limits of the practice and in the process sets forth the director's vision of that practice. In her study of Anderson's work to date, Elizabeth Sussex (1970) quotes the director as stressing his interest in the dynamic that the opposition of the individual to the society generates. ${ }^{12}$ For him, this constituted a source of inspiration for his films, just as his criticism of the lack of foresight exhibited by the film critics and distributors alike, provided the impetus behind his writings about film and the cinema in general. The resulting sense of a confrontation stressing the position that the individual adopts by contrast to the group's, fits in very well with a sequence taken from The White Bus. At the narrative level, the sequence represents the moment when the process of creation and therefore confrontation occurs.

Towards the end of the film, the main protagonist, the Girl, attends a civil defence demonstration along with the other bus passengers. The sequence involves a series of reaction shots of the group as the invited audience of the demonstration. Their reaction remains for the most part subdued throughout a series of simulated emergency scenarios involving amongst others, civil unrest and a nuclear attack. A sense of contrast pervades the sequence. On the soundtrack loud sounds of exploding bombshells, screaming civilians, emergency rescue teams, all contrast starkly with the mute reaction of the White Bus group. Their stillness clashes with the commotion and scenes of panic in the civil demonstration. The sequence culminates in the Girl's companions turning to lifeless dummies while she is seen sitting amongst them. When she stands up to leave, the spot where the demonstration took place has been engulfed in absolute silence. This play on contrasts, involving both sound and picture, works as an effective illustration of the way Anderson conceives of the filmmaking process as a series of interdependent elements that paradoxically threaten the unity of the process.

In 'Creative Elements' which he wrote for Sequence 5 (Anderson, 1948, p.194-9), Anderson explored the successive stages inherent to the filmmaking process. He gave a detailed and precise account of the contribution which each person involved in the production of a film makes, from the producer, the composer, the cameraman, to the scriptwriter and finally the director. The main purpose of the article was to identify the source of creative force(s) behind the film, or as Anderson put it, '... who precisely is responsible for the excellence of any particular film' (ibid., 194). The originality of the article lay in the dual approach that Anderson had adopted: he assessed the function that each contributor made to the filmmaking process, while resisting the temptation to isolate and therefore to privilege one over the 
others. Even when dealing with the role of the film director, Anderson defined his function as the product of a tension, to the extent that he almost contradicted himself. By simultaneously proclaiming the centrality of the director's role and defining the filmmaking process as a fusion of creative elements - interdependent on one another - Anderson presented a precarious view of directorial practice defining the filmmaking process as the 'rare, almost miraculous fusion of many and various creative elements' (ibid., 199). What is noteworthy here is that his statement works on more than one level: the relevance of the concept of an integrated process applies in Anderson's view to the team involved in the production of a film, with the film director as the creative impetus behind the film. To quote from Anderson:

It is a complex series of relationships, susceptible to so many changes of emphasis that all generalisations are sooner or later falsified. But one constant truth emerges - that the evolution of a whole and consistent film demands a rare, almost miraculous fusion of many and various creative elements. Inevitably, perhaps, some critics, soured by prolonged exposure to the second-rate, sell out at last; and proclaim with the loud, selfassuring accents of those who resign from an honourable but fatiguing struggle, that the film is not an art. Only one answer is necessary - that it has been done. It is by their instinctive appreciation of what the critic distils by careful analysis, that the few great men of the cinema have made those rare and treasured works which are to the cinemane ... 'like an amulet against disaster' (ibid.)

In that respect, The White Bus provides a visual metaphor by which to comprehend Anderson's approach to the role of film director.

\section{THE CONSTITUTIVE TENSION AS THE SITE OF A DUALITY BETWEEN CONFRONTATION AND RESOLUTION: THE DIRECTOR AS A LONE FIGURE RELYING ON A PROCESS}

Anderson conceptualised the notion of a necessary confrontation that threatens the unity of the creative process and simultaneously proclaims the authorial presence of the director when he asserted in 'Creative Elements' that the director is 'a central figure that cannot stand alone'. ${ }^{13}$ The film that best exemplifies the implied duality - individuality versus society - is If .... which Anderson directed in 1968. This is a film which provides a visual and thematic expression of the confrontation between the director and the creative elements making up his film and the resulting positioning of the director within that dynamic. Moreover, If.... received critical acclaim on the very basis of the existence of an inherent duality - manifested in the contrary pull of the narrative between documentary style and a surreal account of student life in an English public school.

In an interview for The Observer published at the time of If....'s release, (Anderson, 1968, p.112) Anderson mentioned the key factors which had led to the British distributors' failure to back up the film. One of them is the perceived lack of a tangible storyline. It is true that summing up If .... proves challenging as storyline, narration technique, actors' performance, cinematography, all contribute to make a straightforward reading of the film difficult to achieve. ${ }^{14}$ The available literature on the film usually focuses upon the place - an English public school - the main protagonists - three senior students - and the climax of the film when the three students launch their own revolution on the occasion of their school's Founders' Day and end up shooting at the parents, teachers, chaplain and students alike. The film was released in Britain in December 1968 and proved successful with both the critics and the public. Although the extent of the success of the commercial exploitation of the film 
was limited to London and a few major cities in Britain (Lambert 2000: 146), this was for Anderson his first experience of a box-office success coupled with critical recognition by the industry. The film went on to represent Britain at the 1969 Cannes International Film Festival and won the Palme d'Or on May 25 $5^{\text {th }}, 1969$.

Predictably, the film's perceived revolutionary message struck a powerful chord with the critics - as well as the public - who set out to establish connections between the storyline and the general context of student revolts and social unrest affecting Europe at the time. In an interview for the French cinema journal, Jeune Cinéma (Claude Delmas 1969: 3), for instance, the following question was put to Anderson:

Vous savez sans doute que les drapeaux rouge et noir ont flotté à Paris en mai; or j'ai remarqué que lors de la fugue à moto, les deux écharpes qui flottent au vent sont justement rouge et noire [sic]; est-ce une coincidence? (ibid.)

Translation (by author):

You are undoubtedly aware that black and red flags floated over Paris last May; in that respect, I have noticed that both the scarves floating in the wind in the motorbike escapade scene are also black and red. Is that a coincidence?

His answer captures the essence of his vision for the intended meaning of the film. Speaking of 'significant correspondence'(Delmas, 1969, p.3), he insisted upon the timelessness of the themes covered in If ...., while highlighting the fact that his film had been scripted before the May 1968 events in France. This is a pattern that would repeat itself in subsequent interviews: whenever asked to comment on the social and cultural acuity of his film, Anderson would consistently give an ambiguous answer: ambiguous in the sense that his answer acknowledged the relevance of timing to the understanding of If...., while denying that the general context was at the origin of the film or even that it informed directly its meaning. The 'Notes for a Preface to the Published Script' (Anderson/Sherwin, 1969, p.1203) illustrated the point most convincingly:

Essentially the Public School milieu of the film provides material for a metaphor. Even the coincidence of its making and release with the world-wide phenomenon of student revolt was fortuitous. The basic tensions, between hierarchy and anarchy, independence and tradition, liberty and law, are always with us. (ibid., 120)

The ensuing paradox finds its expression - and resolution - in Anderson's claim to universality for his film. Quoting Dr. Johnson, he claimed that his films aspired to the grandeur of generality; in other words, they aimed to transcend the specific in order to reach a universal value. Anderson for instance declared in 1968, in an interview for The Observer (Anderson, 1968, p.112-5):

Any school - particularly any boarding school - is a microcosm; another inducement for anyone who hankers, as I always do, for that kind of poetry which can claim 'the grandeur of generality'. (ibid., 113)

Anderson's reference to Dr. Johnson's aesthetic concern to strike the right balance between the portrayal of the too familiar - as limited by its temporality - and the outright alien - as pertaining to man's ideal of transcendence, ${ }^{15}$ bridges the gap between Anderson's theoretical writings about the film director's role and the application of these principles to his own directorial practice. In other words it provides an illustration of the tension which 
characterises his working partnership with his collaborators on a film set and equally applies to the storyline and the critical reception of his film If ... at the 1969 Cannes Film Festival.

The reviewers in their majority attributed to the film a dual structure - part documentary, part tragedy - which would account, depending on the critic, for the film's perceived success or failure. Two reviews were particularly indicative of this tendency to read the film as a twotier work: the first was published in the French daily newspaper, Le Figaro on May $10^{\text {th }}$, 1969 (Chauvet, 1969, Le Figaro), before If.... was awarded the Palme d'Or. The reviewer, Louis Chauvet, located the film's failure in the director's 'sudden rupture of tone' between the 'subtle and reserved reportage on the ups and downs of school life' and the sudden twist leading to a 'full-blown tragedy'. The second review, published in Le Canard Enchaîné (Duran, 1969, Le Canard Enchaîné) three days after the close of the Festival, conversely praised the dual structure of the film which the reviewer, Michel Duran, termed 'document et pamphlet'. In Duran's estimation, the duality underpinning If....'s structure, constituted the strength of the film:

...Lindsay Anderson ne se prive pas de fantaisie, mêlant le réalisme absolu au délire de l'imagination, comme il mêle le blanc et le noir à la couleur, déroutant le spectateur trop cartésien, mais possédant l'amateur de cinéma. (ibid.)

Translation (author):

'Lindsay Anderson does not deny himself access to fantasy. He blends the outmost realism with the vagaries of his imagination, just as he mixes together black and white and colour [shots]. In the process he throws off the rational spectator but delights the true cinema lover'.

Michel Duran's review foregrounds the concept of confrontation as one facet of Anderson's directorial practice: Anderson replicated the dynamic between the particular and the universal at all levels of his film: at the level of the storyline, this translates into the director's portrayal of school as a microcosm of society and at the level of the aesthetic of the film, sequences in black and white interrupt the flow of a film shot in colour, which further culminates in the film transcending the expected genre categorisation.

\section{ANDERSON'S DIRECTORIAL PRACTICE AND THE PROCESS OF EQUIVALENCE}

The last facet of the concept of confrontation underpinning Anderson's directorial practice resides in the director's exercise of his role by figuratively borrowing from his collaborators' expertise. Anderson's working partnership with David Sherwin on the scripting of If .... will provide the illustration of what I term the 'process of equivalence' (Gourdin-Sangouard, 2010, p.139-44). One episode in particular helps visualise the process: it involves the removal of a scripted scene and its substitution for another, involving a last-minute artwork collage:

It is interesting that there are some scenes which seem entirely right within the film but which were not in the original script when we began shooting. For example, the scene immediately after Mick is beaten by Rowntree was one I didn't like. We shot it, but I wasn't happy with it. Then, just before we were due to go into the studio for a week's shooting, I realised what the scene should be. David Sherwin came around to my place and we made a series of collages which Mick could have on his study wall and fire darts into. That scene - Malcolm actually did the firing of the darts himself - solved the transition after the beating. Some people dislike the fact that Mike shakes hands with Rowntree after being beaten, but that is what is done in those situations. The criticism 
was that he should be seen as a more overt rebel, but it comes about differently, more interestingly. I felt that his firing darts into the collages broadened the impact and stopped the film being just a school story. (Anderson, 2004b, p.117-8)

The reference to the collage captures the figurative site of the confrontation between the director and the filmmaking process: the site of the confrontation uncovers the nature of Anderson's directorial practice by revealing the destructive potential that his practice assumes for the filmmaking process alongside a more cohesive function. In the quote I aforementioned, Anderson refers to the collage artwork that both he and Sherwin made to feature in the replacement scene. Anderson uses this collage as a means to justify his intervention in his capacity as film director on If ...., thereby asserting the existence of a necessary directorial prerogative: Anderson's comment on the appropriateness of the unscripted scene by contrast to the original scripted one appears to echo his fellow NewWave filmmakers who favoured a strong element of creative latitude for the director when it comes to move from the page to the screen. ${ }^{16}$ François Truffaut for instance argued with respect to the shooting of Les Quatre-Cents Coups/400 Blows (1959) which has often been cited alongside Anderson's If.... for their common homage to Jean Vigo's Zéro de Conduite/Naught for Conduct (1933), that there were key moments in a film that simply could not be scripted in advance. ${ }^{17}$ The reference to Truffaut's directorial practice here highlights the paradox underpinning Anderson's own approach to his role as a film director. If Anderson demonstrates a clear propensity for challenging the work of his scriptwriter when he deems a scene unfit for the final cut of the film, this does not mean however that he regards the discarded scripted material as redundant. Rather, a process of equivalence operates whereby the initial contribution of the scriptwriter enables the director to devise a suitable replacement. Anderson's recollection of the genesis to the collage scene fittingly echoes his own declaration about the significance of the choices he and Sherwin made at the scripting stage regarding set and prop design (Gourdin-Sangouard, 2010, p.136-7; Anderson, 2004b, p.117).

Anderson's and David Sherwin's respective diaries convey most forcefully the human dimension which underlay the two men's collaboration on If..... (Drazin, 2008, p.331-3). The nature of the bond that established itself between Anderson and Sherwin during the scripting and filming stages of If ...., provides the framework within which the concept of confrontation is to be understood. Anderson and Sherwin developed a working relationship that was predicated upon a strong emotional interdependency. One main pattern would repeat itself and involved the director and his scriptwriter assuming in turn the role of the teacher or the student in need of emotional support and tutoring. What is particularly striking about their working pattern is the degree of dependency at one end and the almost total display of control on the other, that each partner demonstrates and this in turn. Each of Sherwin's anxiety attacks over the validity of his drafts complements Anderson's crises of faith in the feasibility of the project, to the extent that they both undermine and re-affirm the existence of a collaborative directorial practice at the heart of If....'s making. The specificity of the practice stems from the sense of balance which characterises the working pattern between the director and his scriptwriter: echoing the principle of fusion within the filmmaking process advocated by Anderson in 'Creative Elements', their collaboration favours an acknowledgement of each contributor's function while proclaiming the interdependent nature of the process itself. As a result, the sense of balance making the process possible is conversely a source of tension, which here makes the collaborative nature of filmmaking both confrontational and fusional. The collage artwork episode I mentioned earlier, brings the paradox to the fore by allowing 
the director's function to supersede the input of the scriptwriter while simultaneously foregrounding the original intent present in the script.

This characterisation of his working pattern captures the salient points of the duality or tension which I have seen as underpinning his directorial practice. The idea of a constitutive tension is fitting as it points to the paradox which leads the director to oppose the other components of the filmmaking process - the 'creative elements' - while re-affirming his need to confront and integrate that very process. This leads us to the final facet of the constitutive tension: that of resolution.

\section{A DUALITY THAT OFFERS ITS OWN RESOLUTION: LINDSAY ANDERSON'S DIRECTORIAL PRACTICE AS A PROCESS OF TENSION AND FUSION}

If... (1968) is divided into eight chapters, each introduced in a way reminiscent of the Hollywood silent film era: the transition to a dark screen featuring an indication of time and location or a line of dialogue. Here the intertitles provide a structure to the narrative of the film by dividing the school year into symbolic milestones. Film critics at the 1969 Cannes International Film Festival, often commented upon Anderson's structuring of his film into episodes. They further related Anderson's choice of narration technique to the perceived documentary value of the film. The connection here provides the framework within which the concept of resolution assumes meaning.

A striking majority of reviews adopted a similar pattern when appraising Lindsay Anderson's If .... They praised the realistic depiction of student life in English public schools while questioning the value of the revolutionary message of the film. In short, they identified in the director's work a discrepancy that would lie in between his ability to document his subject in a realistic way and his unsuccessful treatment of the intended meaning for the film. In The White Bus that was filmed just before If ...., there is a scene which illustrates the existence of a gap within the structure of the film itself.

The scene in question takes places two-thirds into the film and involves the group of tourists, still led by the mayor, attending a production of Bertolt Brecht's Days of the Commune. The song being performed remains unidentified throughout the sequence, and the audience shows virtually no interest in the performance. ${ }^{18}$ The other noticeable feature is the acting practice which the performer is adopting on-stage. The song is in German and there is no indication given to the audience as to its origin; furthermore the performer is wearing a rifle strapped around his chest but hanging at his back. The resulting effect is one of contrast as the spectator gradually becomes aware that the different components of the film confront one another while simultaneously providing a unified vision for the sequence as a whole. The performer embodies the resulting effect of contrast by allowing the structure underlying his performance to become visible.

In an article written for Screen Alan Lovell (1975/6) discussed the perceived Brechtian subtext in Anderson's work. Lovell provided a definition of Bertolt Brecht's own understanding of his role and relationship to the audience as a playwright: he argued that Brecht's work betrayed an awareness of the self-defeating nature of the socialist artist's role: any serious attempt at exposing the inner mechanisms that underlie all works of art implies using the avant-garde art as a platform. However, in doing so, the artist dissociates himself/herself from the 'mass audience' (ibid., 62) whose passive acceptance of the traditional Western 
techniques of representation he or she wants to challenge. Still according to Lovell, Brecht opted to acknowledge the paradox, or tension, inherent to the artist's position and to that end, allowed 'his work [to be] pulled in both directions, [never refusing] the pull of either side'. (ibid., p.62-3) Similarly, Anderson's awareness of his directorial practice works towards acknowledging the existence of the contrary pull and at the same time, implies on his part an attempt at resolving the inherent tension. This highlights Anderson's specific approach to the confrontation of contrasting elements.

In The White Bus, the actor performing the 'Song of Resolution' carries the prop central to the storyline being represented - the rifle as symbol of the uprising in the 1870 Paris Commune - in a manner that challenges the naturalistic depiction of the event which the audience would expect. In other words, the historical accuracy of his costume and prop which the lyrics of the song complement, comes into stark contrast with the actor's un-naturalistic performance of the scene. Just as the audience within the diegesis of The White Bus remains indifferent to the representation taking place on-stage, the performer wears the costume and produces a verbal rendition of the lyrics given to him but does not allow for an assimilation between narrative and narration to occur.

It follows that Anderson's style lies in its constitutive tension which paradoxically endows the director's signature with its unity. The constant tension or movement between homogeneity and dispersion, is what constitutes its Britishness. In 1983, Andrew Higson reviewed two studies of British cinema for Screen (1983, p.80-95); the introductory section to his essay provides within the scope of this paper a framework within which it becomes possible to conceptualise Anderson's directorial specificity (ibid., p.80).

Higson first stressed the primacy of the Hollywood cinema model and French critical theory in terms of evaluating British cinema. He then suggested that the work undertaken in the areas of authorship and genre film in Hollywood heralded an interest in its British counterpart. Two trends in his opinion emerged: the first - in the 60s and 70s - looked at the aesthetic makeup of British cinema and related it to both the 1940s 'Quality films' and the realist tradition; the second, more recent, aimed to identify and study the specificity of British cinema. In the subsequent pages, Higson challenged the extent to which these studies had reached their objective: what is of interest here is Higson's presentation of British cinema as traditionally contingent upon a set aesthetic discourse while still attempting to define its specificity in relation to Hollywood especially. The true specificity of British cinema would thus lie in the acknowledgment of the dominance of one cultural model and the resulting tension in British film discourse. For instance, Higson declares:

The dominant discourse of British film criticism 'writes' British cinema into film cultural memory as a realist cinema, thus effectively blocking off other ways of conceptualising the institution, and working through the question of national cinema... (ibid., 81$)^{19}$

Anderson's directorial practice provides an analogy for the paradox underlying the conceptualisation of British cinema as a distinct mode of film practice. Anderson's exercise of his directorial practice confirms the possibility of a distinct mode of film practice that is nonetheless inscribed within a pre-existing tradition of filmmaking: his personal and professional compulsion to acknowledge and include the expertise of his collaborators into his practice as a director while retaining a distinct authorial signature over the finished film, here provides the analogy. 
Similarly, in 1972 Alan Lovell argued that the British documentary movement - represented by John Grierson, Harry Watt, Basil and Humphrey Jennings to name its most distinguished representatives - would represent Britain's art cinema (Lovell, 1972, p.2). Lovell proceeded to highlight the paradox inherent to his argument:

If one accepts that British documentary is our art cinema, it is tempting to go on and identify the malaise of the British cinema in the paradox that we have produced an art cinema that had no interest in art. (ibid.)

Lovell's characterisation of the British documentary movement is relevant to the present argument in two ways: first, Lovell asserted the distinctiveness of British cinema by categorising it along two trends: utilitarian - 'as a means of instruction and education, as essentially a propaganda medium' (ibid.) - and commercial with the objective of competing with Hollywood (ibid., 5). In that sense, British cinema differed from its European counterparts on more than one level: not only did it share the language of its main competitor, but its version of an indigenous or national cinema failed to conform to the expected pattern consisting of exploring the artistic potential for the medium (ibid., 2). The second aspect of Lovell's argument brought out the existence of another source of tension that also pertained to the definition of a distinct mode of film practice, known as British cinema: the duality underpinning the aesthetic of the British documentary movement. According to Lovell, there exists a contrary pull at the heart of the aesthetic concerns governing the documentary movement (ibid., 4): beyond a mere opposition between an aesthetic project and a utilitarian objective, the documentary movement has become the site of two conflicting visions for the cinema:

\footnotetext{
The distinction is between a position which sees the cinema as a convenient instrument for expressing known ideas where all the film-maker has to do is to express the ideas as simply and forcefully as he knows how, and a position which sees the cinema as a way of apprehending ideas and attitudes ... in which the attempt to shape and control a film is closely linked with the attempt to apprehend the ideas and attitudes. (ibid.)
}

Within the present context, Lovell's characterisation of the British cinema provides a framework of reference for Anderson's directorial practice: that is, one which seeks to assert its aesthetic concern while retaining a distinctly British approach to the filmmaking process. Whereas in Europe ' 'art cinema' has come more and more to mean a cinema of selfconscious stylistic innovation and formal experiment' (ibid., 2), Anderson has strived to achieve personal poetry through the integration of each component underpinning the filmmaking process. ${ }^{20}$ 


\section{REFERENCES}

Anderson, L. (1947) 'Angles of Approach', Sequence 2, Winter. In: Ryan, P. (2004) ed., Never Apologise: The Collected Writings of Lindsay Anderson. London: Plexus, 189-93.

Anderson, L. (1948) 'Creative Elements'. Sequence 5, Autumn. In: Ryan, P. (2004) ed., Never Apologise: The Collected Writings of Lindsay Anderson. London: Plexus,, 194-9.

Anderson, L. (1956) 'Stand up! Stand Up!'. Sight and Sound, Autumn. In: Ryan, P. (2004) ed., Never Apologise: The Collected Writings of Lindsay Anderson. London: Plexus, 218-32.

Anderson, L. (1968) 'School to Screen. The Observer, December. In: Ryan, P. (2004) ed., Never Apologise: The Collected Writings of Lindsay Anderson. London: Plexus, 112-5.

Anderson, L. \& Sherwin, D. (1969). 'Notes for a Preface to the Published Script of If .... '. In: Ryan, P. (2004) ed., Never Apologise: The Collected Writings of Lindsay Anderson. London: Plexus, 120-3.

Anderson, L. (2004a) Sutton, P. ed., Lindsay Anderson: Diaries. London: Methuen.

Anderson, L. (2004b) Ryan, P. ed., Never Apologise: The Collected Writings of Lindsay Anderson. London: Plexus.

Anderson, L. - Lindsay Anderson Collection - University of Stirling Library Special Collections: LA 1/4/: The White Bus

LA 6/1/ Personal Diaries

Chauvet, L. (1969) (Untitled Extract) Le Figaro, 10 mai, Dossier Archives - Festival de Cannes 1969 - Revue de Presse AFP - Côte FIFP 312 B12, Bibliothèque du Film (BiFi) - Paris.

Curran, J. \& Porter, V. eds. (1983) British Cinema History. London: Weidenfeld \& Nicholson.

Delaney, S. (1964) Sweetly Sings the Donkey. London: Methuen.

Delmas, C. (1969) 'Lindsay Anderson; en 69 comme en 57: contestataire', Jeune Cinéma, Revue Mensuelle de la Fédération Jean Vigo des Ciné-Clubs de Jeunes et des Cercles de Culture par le Film, Paris, 39, 1-10.

Duran, M. (1969) «If... [sic] (Le collège détone) [sic] », Le Canard Enchaîné, 28 mai, Revue de Presse Numérisée If.... - Bibliothèque du Film (BiFi) - Paris.

Drazin, C. (2008) 'If.... Before If....'. Journal of British Cinema and Television, 5/2, 318-334.

Gourdin-Sangouard, I. (2010) 'Creating Authorship? Lindsay Anderson and David Sherwin's Collaboration on If.... (1968)'. Journal of Screenwriting 1/1, 131-148.

Hedling, E. (1998) Lindsay Anderson: Maverick Film-Maker. London: Cassell

Higson, A. (1983) 'Critical Theory and 'British Cinema': Andrew Higson Considers Two New Studies’. Screen, 24/4, 80-95. 
Lambert, G. (2000) Mainly about Lindsay Anderson: A Memoir. London: Faber \& Faber Ltd.

Lay, S. (2002) British Social Realism: From Documentary to Brit Grit. London: Wallflower Press.

Leach, J. (2004) British Film. Cambridge: Cambridge University Press.

Lovell, A. (1972) 'The Unknown Cinema of Britain'. Cinema Journal. 11/2, 1-8.

Lovell, A. (1975-6) 'Brecht Event V: Brecht in Britain - Lindsay Anderson (on If... [sic] and O Lucky Man!)' Screen, 16/4, 62-80.

Manvell, R. (1966) New Cinema in Europe. London: Studio Vista.

Marcorelles, L. [trans. R. Roud] (1960) 'Views of the New Wave'. Sight \& Sound, 29/2, 84-85.

Pilard, P. (1996) Histoire du Cinéma Britannique. Nathan Université, Paris: Editions Nathan.

Sachs, A. (1965) 'Generality and Particularity in Johnson's Thought'. Studies in English

Literature: 1500-1900. 5/3, 491-511.

Sherwin, D. (1997) Going Mad in Hollywood, and Life with Lindsay Anderson.

Harmondsworth: Penguin Books Ltd.

Sinker, M. (2004) If.... London: BFI.

Sussex, E. (1970) Lindsay Anderson. New York: Praeger.

\section{FILMOGRAPHY}

A Bout de Souffle/Breathless (1959). Directed by Jean-Luc Godard, France, Les Productions Georges de Beauregard.

Hiroshima, Mon Amour (1959). Directed by Alain Resnais, France, Argos Films.

If ... (1968). Directed by Lindsay Anderson, UK, Memorial Enterprises.

Is That All There Is? (1993). Directed by Lindsay Anderson. UK, BBC Scotland/Yaffle Films.

Les Quatre-Cents Coups/400 Blows (1959). Directed by François Truffaut, France, Les Films du Carrosse.

The White Bus (1967). Directed by Lindsay Anderson, UK, Holly.

Zero de Conduite: Jeunes Diables au CollegelZero for Conduct (1933). Directed by Jean Vigo, France, Franfilmdis/Argui-Film. 


\section{NOTES}

${ }^{1}$ In 1948 Anderson wrote and directed a documentary about a firm making conveyor belts in Yorkshire: Meet The Pioneers. Lois Sutcliffe - the wife of the managing director - had met Anderson at the annual meeting of the Federation of Film Societies in 1947. She and her husband had been repeatedly thwarted in their attempts to give a human dimension to the presentation of their business. She was convinced that Anderson was the right man for the job, which marked the beginning of a life-long friendship. She was with him when he died suddenly while on holiday in France in 1994.

${ }^{2}$ Is That All There Is, first broadcast in September 1994. The documentary allowed the spectator access to Anderson's inner circle of friends and daily routine thereby affording the film director an opportunity to reflect upon his career as a film director.

${ }^{3}$ From 1946 until 1952, Lindsay Anderson along with fellow Oxford students Peter Ericsson, John Boud, coedited the film magazine Sequence. Gavin Lambert, Anderson's school friend at Cheltenham College, was also an active contributor before he became the editor of the BFI magazine, Sight and Sound.

${ }^{4}$ Lindsay Anderson (2004b: 215): ‘... I persist in believing that film people get the worst of it. Other critics may be wrong; but at least they rarely boast of their ignorance. Films seem to make them aggressive: they want to attack, not merely the craftsmen, but the art itself ... The cinema, it is clear, is anybody's game'.

Anderson (1956: 221): ' ... there is another kind of philistinism, timorous rather than pugnacious, which shrinks from art because art presents a challenge ... Miss Lejeune, having just declared that a film is nothing but 'bits of celluloid and wire', 'I am not intending to belittle the screen.' And I do not suppose that this is the conscious intention of the other critics I have quoted, either. But this is what they are doing'.

5 Anderson (1947: 193): ‘ ... It means allowing every film to justify itself by its own standards, not by our preconceptions'.

${ }^{6}$ Sussex (1970: 58): 'The White Bus ... is the kind of film I wanted to make and am quite proud of having made'.

7 The Programme Notes for Gary Sweet's Showing of The White Bus at the North Texas State University in December 1979 in Dallas, US, account for the shift from the initial creative freedom Oscar Lewenstein gave Karel Reisz, Tony Richardson and Lindsay Anderson, to the eventual decision of using Shelagh Delaney's book of short stories as a common source of inspiration: ' ... I liked the story and I liked Shelagh, and I agreed to do it. Tony Richardson hit on another story from the same collection, and it was decided that the 'trilogy' should take a more defined form, of three different directors working on material provided by Shelagh Delaney'. Anderson (1979: LA 1/4/5/1)

8 Lindsay Anderson in his interviews with Paul Ryan in the 1990s however, skips Karel Reisz's initial participation and suggests Oscar Lewenstein only invited him, Tony Richardson and Peter Brook to contribute a segment to the project. See Anderson (2004b: 105).

${ }^{9}$ When Tony Richardson and Peter Brook saw The White Bus they immediately decided that they should try and make something more remarkable and they jettisoned Shelagh Delaney. Lindsay Anderson (2004b: 107)

${ }^{10}$ Anderson (2004b: 107): ' '.. The whole thing made no sense. I certainly don't blame United Artists for not distributing it'.

${ }^{11}$ Sussex (1970: 57): 'Critics are simply the equivalents in journalism of the film distributors in the industry'.

12 Sussex (1970: 58): '[Anderson] draws attention to the theme recurring throughout his work - 'the tension between being alone and an almost nostalgic feeling of belonging to a group or community'...'

13 Anderson (1948:199)'So, in this gathering together, this fusion, there must be a central figure, one man conscious of the relative significance of every shot, the shape and flow of every sequence. But he cannot stand alone; he stands with, dependent on, his author and his cameraman'. 
${ }^{14}$ Elizabeth Sussex (1970) only provides a very succinct summary of the action (70-1: 'If... [sic] is set in what Anderson has described as 'a fictitious, but extremely authentic public school', and shows how three rebels are finally driven into staging a violent revolt against everything the place stands for'. Mark Sinker (2004) offers a comprehensive overview of the main themes and stylistic concerns underlying If...., as well as provides an extensive background to the scripting and making of the film. His study however does not include a summary of the narrative.

15 Arieh Sachs (1965: 491-2): 'Perhaps the first thing to notice concerning the role of generality and particularity in Johnson's view of man is the idea that ... man's real being, unlike that of beasts, is essentially defined by the contradiction between a transcendence and its employments in time'.

${ }^{16}$ See for instance Louis Marcorelles (1960: 84): “ The credits of A Bout de Souffle list François Truffaut as screenwriter and Claude Chabrol as 'artistic supervisor'; but this was done for the benefit of the technicians' union and, in fact... Truffaut's contribution was the discovery of a news snippet which became the starting point of the plot. A Bout de Souffle is therefore a genuine film d'auteur-more so than either Les Quatre-Cents Coups or Hiroshima, Mon Amour, to which the screenwriters made powerful contributions'.

17 'I work practically without a shooting script; all I prepare is the dialogue [...] You can't put the best moments of a film down in a script' (Truffaut in Manvell 1966: 69).

18 Lindsay Anderson (2004a: 138): Note 1: 'Anthony Hopkins makes his film debut singing ['Song of Resolution']...'. Erik Hedling (1998: 66) indicates that 'Brecht's last original drama, written in Zuerich [between] 1948 [and 1949] had not then been translated into English and had never been performed in Britain'.

${ }^{19}$ The study in question is: James Curran and Vincent Porter eds. (1983), British Cinema History

${ }^{20}$ See also Alan Lovell (1972: 4-5): 'A crippling effect of making the distinction [between propagandists and aesthetes] such a simple one has been the persisting notion in the British cinema of 'poetry', where poetry is seen as something imposed on the film'. 